\title{
Gabriel Weston: Fresh thinking on bacteria
}

\author{
Gabriel Weston ENT surgeon
}

Surrey

The garden is alight with sun. I've got the radio on and some seeds in my hand, and I'm ruing the habit of discriminating between good and bad bacteria.

Maybe it's this moralistic approach to nature that's stopped me realising what an amazing organism the recently renamed Clostridioides difficile is. After all, doesn't it seem prurient to take an interest in this bug, which is the biggest cause of nosocomial diarrhoea worldwide and has been slapped with the most severe warning level by the US Centers for Disease Control and Prevention? It's surely right that, when I flew to the US with the BBC a few years ago to film the gastroenterologist Colleen Kelly using faecal microbiota transplant to vanquish an intractable case of $C$ difficile in a patient, ${ }^{1}$ we turned our camera on the cure for this devastating infection rather than revelling in its cause.

But, in sneaky solitude, I've luxuriated this week in the fascinating world of this bacterium. I love the mistakes and revelations of its history. I'm engaged by the diagnostic dilemmas. I'm in awe of its dynamic ability to produce new strains. And, most of all, I'm gripped by its shapeshifting powers.

$C$ difficile needs two guises: a "spore" for transmission and a "vegetative" form for destruction. The spore is like a gobstopper, its arsenal encased in seven different protective shells, inuring it to heat, disinfectants, and radiation. The outermost exosporium even has little projections to help it stick to hospital bedding.

Once swallowed, the dormant spore passes, untouched by the acid onslaught of the stomach, into the small intestine. In a healthy gut it does nothing. But, if antibiotics have sufficiently disrupted the microbiological environment, it's action stations. A drop in the usual products of bacterial metabolism-for example, the secondary bile salt chenoxycholate-and a rise in precursors, such as the primary bile salt cholate, prompts germination. Once transformed into its vegetative form, $C$ difficile produces more spores, but it also makes toxins that wreak havoc on the large intestine by dissolving its epithelium.

So, I'm marvelling at the presumably infested soil, guarding my shameful $C$ diff zeal, when the physicist Paul Davies comes on the radio and makes me feel a whole lot better. A researcher of everything from Martians to theology, he's been invited to help solve some of the chewiest conundrums in cancer research. Why a physicist? For one simple reason, he explains: revelations come from curiosity. And doctors have become so bound up with seeing cancer as the enemy, they're no longer able to bring fresh, wondering eyes to figuring it out.

I like this springtime thinking. I spill a sachet into my hand and start to poke little holes in the ground. Who knows whether I'll have anything to show for it this year? But I sure as hell won't grow a single radish if I don't start by planting these seeds.

Competing interests: I have read and understood BMJ policy on declaration of interests and declare that I have no competing interests.

Provenance and peer review: Commissioned; not externally peer reviewed.

1 BBC Two. Trust Me, l'm a Doctor: What does a faecal transplant do? 2015. https://www. bbc.co.uk/programmes/articles/27bZmcvpXj5kBnC6c5mB2K6/what-does-a-faecaltransplant-do.

Published by the BMJ Publishing Group Limited. For permission to use (where not already granted under a licence) please go to http://group.bmj.com/group/rights-licensing/ permissions 